\title{
A Preliminary Study of Banana Stem Juice as a Plant-Based Coagulant for Treatment of Spent Coolant Wastewater
}

\author{
Habsah Alwi, ${ }^{1}$ Juferi Idris, ${ }^{2}$ Mohibah Musa, ${ }^{1}$ and Ku Halim Ku Hamid ${ }^{1}$ \\ ${ }^{1}$ Faculty of Chemical Engineering, Universiti Teknologi MARA, Malaysia, 40450 Shah Alam, Selangor, Malaysia \\ ${ }^{2}$ Faculty of Chemical Engineering, Universiti Teknologi MARA, Sarawak Campus, 94300 Kota Samarahan, Sarawak, Malaysia
}

Correspondence should be addressed to Juferi Idris; juferi@sarawak.uitm.edu.my

Received 5 October 2012; Revised 17 December 2012; Accepted 21 January 2013

Academic Editor: Shayessteh Dadfarnia

Copyright (C) 2013 Habsah Alwi et al. This is an open access article distributed under the Creative Commons Attribution License, which permits unrestricted use, distribution, and reproduction in any medium, provided the original work is properly cited.

\begin{abstract}
The effectiveness of banana stem juice as a natural coagulant for treatment of spent coolant wastewater was investigated. Three main parameters were studied, namely, chemical oxygen demand (COD), suspended solids (SSs), and turbidity of effluent. Coagulation experiments using jar test were performed with a flocculation system where the effects of spent coolant wastewater $\mathrm{pH}$ as well as banana stem juice dosage on coagulation effectiveness were examined. The highest recorded COD, SS, and turbidity removal percentages by banana stem juice were $80.1 \%, 88.6 \%$, and $98.5 \%$, respectively, observed for effluent at $\mathrm{pH} 7 \mathrm{using} 90 \mathrm{~mL}$ dosage. The inulin concentration in the banana stem was examined to be $1.22016 \mathrm{mg} / \mathrm{mL}$. It could be concluded that banana stem juice showed tremendous potential as a natural coagulant for water treatment purposes and could be applied in the pretreatment stage of Malaysian spent coolant wastewater prior to secondary treatment.
\end{abstract}

\section{Introduction}

Coolant is widely used to provide a degree of lubrication and for cooling in various metal-working operations. It also improves the machinability, increases productivity, and extends tool life by cooling and lubricating the parts and cutting tools. They are largely based on water-soluble oils: synthetic, semisynthetic, and biodegradable [1]. The main problem with coolants, however, is that they can easily become polluted over long use, losing their effectiveness and properties [2], and may develop rancid odours due to the presence of complex chemicals and biocides [3]. Thus, a large amount of spent coolant wastewater generated from metalworking operations which is generally in high COD (Table 1) has become a great concern for the manufacturing industries. Due to its high surface-active and organic pollutant loads, this waste creates a serious danger to the environment $[2,4,5]$. It is estimated that more than $2 \times 10^{9}$ litres of metal-working fluids (MWFs) were used worldwide annually, and the waste could be more than ten times the usage, as the coolants have to be diluted prior to use [3].
There are several treatment methods used to treat waste metal-cutting fluids [2], namely, chemical coagulation [6], adsorption [7], microfiltration, and ultrafiltration [8-10], as well as biological (aerobic and anaerobic) process [11-14]. Due to high energy consumption or application of variety of chemicals, this would decrease the processing efficiency and increase cost of process [15]. For biological treatment, large area requirement, high maintenance, long retention time, and odour problems are usually associated with pond treatment methods.

Coagulation is a common process in the treatment of both industrial wastewater and surface water. Its application includes the removal of dissolved chemical species and turbidity via the addition of widely used chemical-based coagulants such as alum $\left(\mathrm{AlCl}_{3}\right)$, ferric chloride $\left(\mathrm{FeCl}_{3}\right)$, polyaluminium chloride (PAC), and synthetic polymer. Nonetheless, many disadvantages are associated with the usage of these coagulants such as relatively high procurement costs as well as detrimental effects on human health and environment. It is, therefore, the use of natural organic coagulant from plantbased which is cost effective may be an interesting alternative. 
TABLE 1: The characteristics of MWF $[2,3,12,21-24]$ and regulatory discharge standard limits [32].

\begin{tabular}{lccc}
\hline Parameters & $\begin{array}{c}\text { MWF } \\
\text { effluent } \\
(\mathrm{mg} / \mathrm{L})\end{array}$ & $\begin{array}{c}\text { Regulatory standard } \\
\text { discharge limit }(\mathrm{mg} / \mathrm{L})\end{array}$ \\
\hline $\mathrm{pH}$ & 7.06 & $6.0-9.0$ & $5.5-9.0$ \\
Chemical oxygen & $560-68000$ & 50 & 100 \\
$\begin{array}{l}\text { Demand (COD) } \\
\text { Suspended solid (SS) }\end{array}$ & 110 & 50 & 100 \\
Turbidity & $15,350 \mathrm{NTU}$ & - & - \\
Color & White & - & - \\
\hline
\end{tabular}

All values except for $\mathrm{pH}$ and turbidity are expressed in $\mathrm{mg} / \mathrm{L}$.

Banana is a herbaceous plant of the genus Musa spp. of the family Musaceae. Banana is one of the most widely grown tropical fruits because of its high food value and an important addition to the diet. In Malaysia, the production of commercial varieties of banana has increased by $24-27 \%$ over the decades giving an amount of 27,453 hectares in 2009 with Johor, Pahang, and Sarawak as the largest banana-producing states [16]. The stem from which the fruit bunches have been taken should be cut off because it will never again grow fruit. The stem will be left abundantly in the plantation and normally will just rot or be used as fertilizer.

According to Namasivayam et al. [17], waste banana pith can be used effectively as an adsorbent for the removal of $87 \%$ Rhodamine B from textiles wastewaters at $\mathrm{pH} 4$. Another research also on colour removal showed that the pith of banana stem can effectively remove the direct red colour and acid brilliant blue from aqueous solution through adsorption. The adsorption capacities were 5.92 and $4.42 \mathrm{mg}$ dye per gram of pith for direct red and acid brilliant blue, respectively [18] Other than that, banana pith also could be a useful biosorbent in the preliminary removal of cuprum from electroplating wastes [19]. The usage of banana stem juice as a natural coagulant in COD, SS, and turbidity removal, however, is known to be limited in the published literature.

This paper reports on the potential of juice produced from banana stem as a natural coagulant for the removal of COD, SS, and turbidity from spent coolant wastewater. Jar test with a flocculation system was used and the effects of spent coolant wastewater $\mathrm{pH}$ on coagulation effectiveness were examined. The coagulation/flocculation effectiveness of the banana stem juice was compared with Malaysian standard effluent discharge limit.

\section{Experimental}

Spent coolant wastewater was collected from camera lens manufacturer company in Shah Alam, Selangor, Malaysia. The spent coolant wastewater was collected from the site with excessive oil from the machine-processing operation. The oil on the top of the coolant was separated through skimming process, and spent coolant wastewater (without any excessive oil) was collected at the spent coolant storage prior to the treatment process within the plant operation.

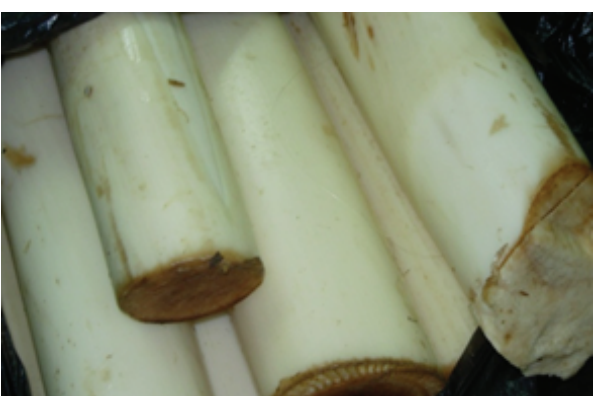

Figure 1: Pith of banana stem after separated with foliage.

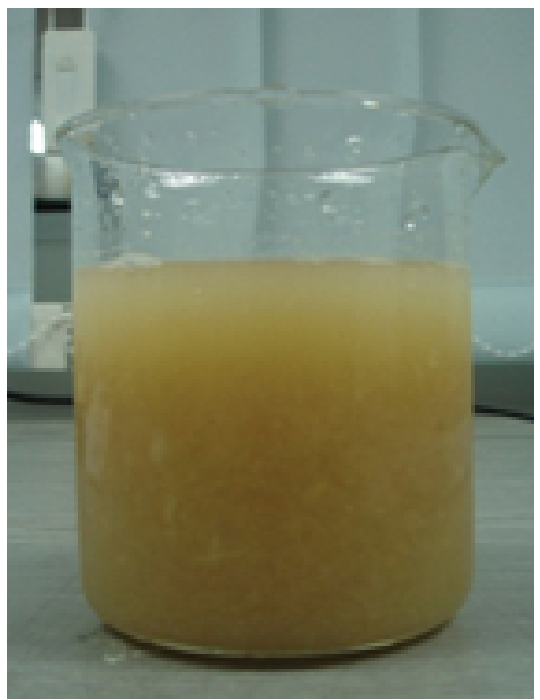

FIgUre 2: The banana stem juice.

The samples were collected in accordance with standard method for the examination of water and wastewater [20]. The samples were transferred into $20 \mathrm{~L}$ plastic containers and then closed, sealed tight, and labelled to avoid any oxidation and contamination before being transported to the laboratory. The samples were stored at $5^{\circ} \mathrm{C}$ to prevent spent coolant wastewater from undergoing further biodegradation due to microbial activities.

2.1. Banana Stem Juice Preparations. Matured banana plants were collected from Serdang, Selangor, Malaysia. The thorns were removed and the pith of the stem (Figure 1) was then separated from the foliage. $100 \mathrm{~g}$ of small pieces of the pith were mixed with $10 \mathrm{~mL}$ of distilled water using a mixer. The mixed pith was then filtered and the juice was collected. The fresh juice of banana stem (Figure 2) was stored in a refrigerator at $7^{\circ} \mathrm{C}$ to ensure its freshness. To avoid any fermentation, the coagulation experiments using this banana stem juice as a natural coagulant were carried out on the same day.

\section{Methods}

3.1. Coagulation Jar Test Experiments. Coagulation experiments using jar test were performed in the laboratory 
with a bioblock flocculation that comprises six-paddle rotor $(24.5 \mathrm{~mm} \times 63.5 \mathrm{~mm})$ for $600 \mathrm{~mL}$ high-shape beakers, and all tests were conducted at room temperature. The desired amount of coagulant was added to spent coolant wastewater and stirred at the "flash mixing" speed of approximately $120 \mathrm{rpm}$ for 1 minute. The speed was then reduced to slow at $30 \mathrm{rpm}$ for 20 minute to keep flocs particles uniformly suspended. The settling of flocs particles was then observed and recorded. The mixture was left for 1 hour and later the supernatant was collected to determine the COD, SS and turbidity using the standard method. All the analyses were done in triplicates. $\mathrm{pH}$ of wastewater samples was controlled by adding $1.0 \mathrm{M} \mathrm{H}_{2} \mathrm{SO}_{4}$ or $1.0 \mathrm{M} \mathrm{NaOH}$.

3.2. Analytical Analysis. Turbidity test was measured using portable turbidimeter (Model HACH 2100P). The principle of the turbidity measurement is based on a comparison of the intensity of light scattered by the sample. The sample cell was placed into the turbidimeter and the turbidity value was shown in NTU unit. The total turbidity percentage removal was calculated as follows:

$$
\text { turbidity percentage removal } \approx \frac{A-B}{C} \times 100,
$$

where $A$ is turbidity of raw spent coolant wastewater (NTU), $B$ is turbidity after treatment (NTU), and $C$ is turbidity of raw spent coolant wastewater (NTU).

$\mathrm{pH}$ meter brand Mettler Toledo was used in this paper to measure the $\mathrm{pH}$ value of the sample. Suspended solid was measured using glass fiber disk filtration method. The glass fiber filter disks were dried in the oven at $100-105^{\circ} \mathrm{C}$ for one hour to remove any moisture that can affect the suspended solid measurement. The dried filter disk was then cooled and weighted. It was then used to filter $10 \mathrm{~mL}$ of the supernatant using vacuum filter, and the disk was carefully washed using $10 \mathrm{~mL}$ of distilled water. The disk was then dried again at 100$105^{\circ} \mathrm{C}$ for one hour and weighted again after it was cooled. The total suspended solid removal percentage was calculated as follows:

$$
\text { suspended solid } \approx \frac{A-B}{C} \times 10^{6},
$$

where $A$ is weight of the disk + solids ( $\mathrm{g}$ ), $B$ is weight of empty filter disk (g), $C$ is volume of sample $(\mathrm{mL})$.

The COD test was measured using UV Spectrophotometer HACH model. Chemical oxygen demand (COD) refers to the amount of oxygen required to oxidize the organic compounds in a water sample to carbon dioxide and water. COD percentage removal was calculated as follows:

$$
\text { COD percentage removal } \approx \frac{A-B}{C} \times 100,
$$

where $A$ is COD of raw spent coolant wastewater $(\mathrm{mg} / \mathrm{L}), B$ is COD after treatment $(\mathrm{mg} / \mathrm{L})$, and $C$ is COD of raw spent coolant wastewater $(\mathrm{mg} / \mathrm{L})$.

3.3. CHN Analysis. Analysis of constituents in banana stem was determined using the CHNS/O Analyzer LECO,
TABLE 2: Characteristics of spent coolant wastewater.

\begin{tabular}{lc}
\hline Parameter & Raw spent coolant wastewater \\
\hline $\mathrm{pH}$ & 8.45 \\
Chemical oxygen demand & $152,400 \mathrm{mg} / \mathrm{L}$ \\
Suspended solids & $8,880 \mathrm{mg} / \mathrm{L}$ \\
Turbidity & $81,250 \mathrm{NTU}$ \\
Color & White \\
\hline
\end{tabular}

CHNS932. Approximately $2.0 \mathrm{mg}$ of very fine cut of oven dried banana stem was placed in a tin capsule and crimped. Three types of crimped capsules were placed in the autosampler for the CHNS/O analyzer (blank, standard-sulfamethazine, and banana stem sample). The temperature of the analyzer oxidation was set at $1000^{\circ} \mathrm{C}$. A program runs the analysis automatically and results were given in percentage.

3.4. Inulin Analysis. Inulin analysis in banana stem was determined using high-performance liquid chromatography (HPLC) Agilent 1200. Standard inulin was obtained from a company in Subang, Selangor, Malaysia, with approximately 99\% purity. Before injecting for analysis, the juice was filtered using nylon acrodisc filter $0.45 \mu \mathrm{m}$ to avoid any interference. Shodex column K806 with $\mathrm{NaNO}_{3} 0.5 \mathrm{M}$ as eluent has been set. The flow rates of injection were $1 \mathrm{~mL} / \mathrm{min}$ with $200 \mu \mathrm{L}$ injection volume. The detector used was refractive index for analysis of carbohydrates component. The data for standard inulin was used to construct the calibration curve. The peak of inulin on the juice sample was recorded. The concentration of inulin was calculated based on the standard inulin calibration curve.

\section{Results and Discussion}

4.1. Characterization of Raw Spent Coolant Wastewater. Table 2 shows the characteristics of spent coolant wastewater before the coagulation pretreatment. The values were much higher compared to previous results [2, 3, 12, 21-24] except for $\mathrm{pH}$ and color. The differences were due to the machinery sources processing the wastewater, and this was indicated by the spent coolant wastewater containing high inorganic and organic substances. It is obvious that treatment of wastewater is required before it can be discharged into the environment since the COD concentration alone is more than 1500 times higher than the Standard B discharge limit.

4.2. CHN Analysis. An elemental analysis (Table 3) was conducted to provide a comparison between the elemental compositions of the banana stem and banana stem juice with those of other natural coagulants: Moringa oleifera and cactus Opuntia. In this study, it was determined that the foliage of banana stem contained $38.03 \%$ carbon, $0.42 \%$ nitrogen, and $5.46 \%$ hydrogen, meanwhile the stem juice contained $33.42 \%$ carbon, $0.49 \%$ nitrogen, and $6.17 \%$ hydrogen.

The composition of hydrogen was higher in banana stem juice compared to the banana stem. This is due to the highmoisture composition of that compared to the banana stem. The composition of principal elements of the banana stem 
TABLE 3: Elemental analysis of banana stem, banana stem juice, and comparison with other natural coagulants.

\begin{tabular}{lcccccc}
\hline Parameters & $\begin{array}{c}\text { Shelled Moringa } \\
\text { seeds [33] }\end{array}$ & $\begin{array}{c}\text { Nonshelled } \\
\text { Moringa seeds [33] }\end{array}$ & $\begin{array}{c}\text { Cactus Opuntia } \\
{[34]}\end{array}$ & $\begin{array}{c}\text { Banana stem } \\
\text { (pseudostem) [25] }\end{array}$ & Banana stem & Banana stem juice \\
\hline C (\%) & 54.8 & 53.3 & 29.4 & 36.83 & 38.03 & 33.42 \\
N (\%) & 6.1 & 5.0 & 2.3 & 5.19 & 0.42 & 0.49 \\
H (\%) & 8.5 & 7.7 & 1.7 & 0.93 & 5.46 & 6.17 \\
\hline
\end{tabular}

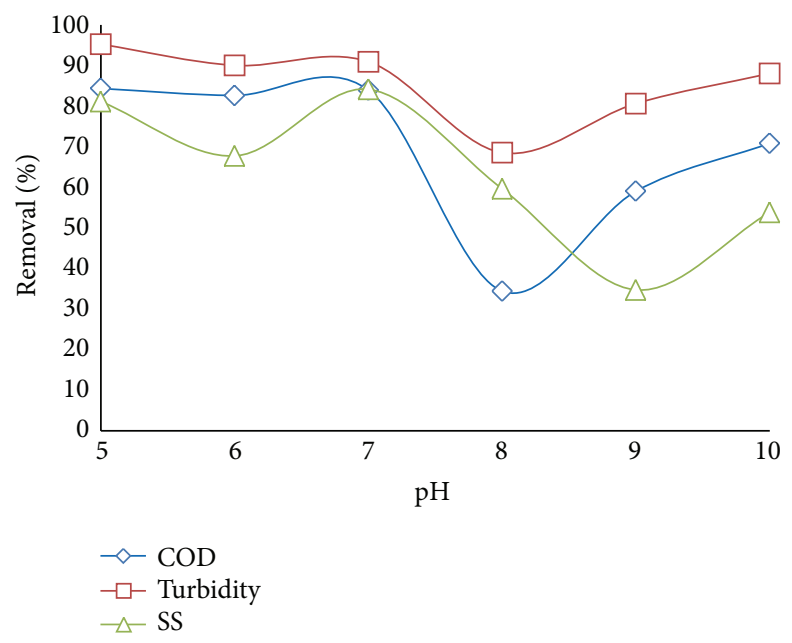

FIGURE 3: Effect of spent coolant wastewater $\mathrm{pH}$ on banana stem juice coagulant effectiveness.

was nearly similar with the result obtained by Bilba et al. [25]. They found that the compositions of carbon, hydrogen and nitrogen of the core of banana stem (pseudostem) were $36.83 \%, 5.19 \%$, and $0.93 \%$, respectively. There were not many differences between the compositions of carbon, hydrogen, and nitrogen in banana stem/juice and the established plantbased coagulants such as nonshelled Moringa seeds and shelled Moringa seeds.

4.3. Inulin Analysis. From the HPLC result, the peak of inulin was at 10 - to 15-minute retention time, and the peak area that has been recorded was equal to 8191004.35 . The result showed that inulin can be found in the stem of banana trees, and this is in agreement with the study by Meijer and Mathijssen [26], where most of the inulin is stored in the stem of chicory and Jerusalem artichoke. The result from this study showed that the inulin concentration in the banana stem was $1.22016 \mathrm{mg} / \mathrm{mL}$.

Inulin is a very stable compound; Tadros et al. [27] discovered that the unique behaviour of the polymeric surfactant based on inulin is very stable on high temperature and also can be very stable emulsions in high electrolyte concentrations. Inulin has high bonding capacity as mentioned by Eissens et al. [28]. With this high bonding capacity, it is able to entrap more microfloc to form bridges on the polymer chain of inulin structure. When all the microflocs attached to the polymer chain of the inulin, this will form bigger and heavier flocs. The heavier flocs will easily settle down through the sedimentation process. Therefore, the settlement of the suspended solid will reduce the turbidity and the COD of the sample waste in flocculation process during jar test analysis.
4.4. Effect of $p H$ on Banana Stem Juice. The chemistry of coagulant depends on the $\mathrm{pH}$ of any solution during the flocculation process. This can be seen when ferric salts undergo rapid, uncontrolled hydrolysis reactions upon their addition to water, forming a series of chemical products or complexes [26]. Therefore, controlled $\mathrm{pH}$ of the spent coolant wastewater determines the effectiveness of banana stem juice in the flocculation process, where it determines the maximum COD, SS, and turbidity percentage removal. Figure 3 shows the effect of $\mathrm{pH}$ on the coagulation of the spent coolant wastewater using banana stem juice as a natural coagulant. The volume of spent coolant wastewater used was $300 \mathrm{~mL}$ and the volume of banana stem juice used was $50 \mathrm{~mL}$. From the graph, the highest recorded COD and SS removal percentage was observed for effluent $\mathrm{pH} 7$ at $83.9 \%$ and $84.1 \%$, respectively. However, percentage removal for turbidity at $\mathrm{pH}$ 7 was found slightly less $(90.9 \%)$ compared to the percentage removal at $\mathrm{pH} 5$ (highest percentage removal, 95.2\%). Generally, $\mathrm{pH} 7$ was found to be a good $\mathrm{pH}$ for efficient removal of COD, SS, and turbidity by banana stem juice, where the percentages were at $83.9,84.1$, and $90.9 \%$, respectively. This result indicated that at $\mathrm{pH} 7$, the maximum amount of coagulant is converted to solid phase flocs particles. At $\mathrm{pH}$ value higher and lower than this $\mathrm{pH}$ of minimum solubility, the charges produced by inulin as a natural polymer from banana stem juice for bridging and entrapping the microfloc to form larger floc were very low; thus, the adsorption on the surfaces of precipitated floc particles was very minimal. This result is rather different compared to plant-based coagulant such as Opuntia ficus-indica with coagulating-flocculating capabilities where $65 \%$ of the initial COD was removed at 


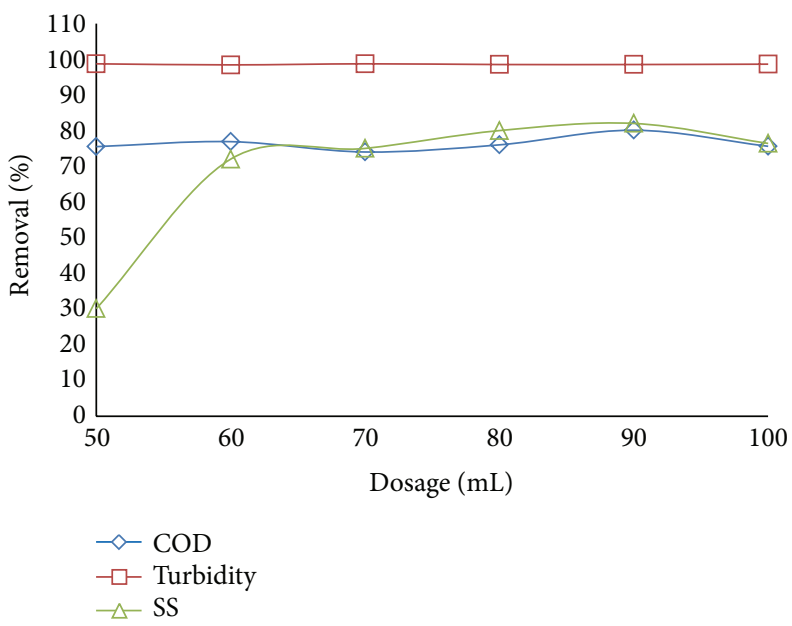

FIGURE 4: Effect of banana stem juice dosage on the coagulation process of spent coolant wastewater.

TABLE 4: Compliance of treated spent coolant wastewater using banana stem juice with Malaysian standard effluent discharge limit.

\begin{tabular}{lcccc}
\hline Parameters & $\begin{array}{c}\text { Raw spent coolant } \\
\text { wastewater }(\mathrm{mg} / \mathrm{L})\end{array}$ & $\begin{array}{c}\text { Treated spent coolant wastewater }(\mathrm{mg} / \mathrm{L}) \\
\text { banana stem juice }\end{array}$ & \multicolumn{2}{c}{ Standard effluent discharge limit (mg/L) } \\
\hline $\mathrm{pH}$ & 8.45 & 7 & $6.0-9.0$ & $5.5-9.0$ \\
$\begin{array}{l}\text { Chemical oxygen } \\
\text { Demand (COD) }\end{array}$ & 152,400 & 30,300 & 50 & 100 \\
$\begin{array}{l}\text { Suspended solid } \\
\text { (SS) }\end{array}$ & 8,880 & 1,010 & 50 & 100 \\
Turbidity & $81,250 \mathrm{NTU}$ & $1,235 \mathrm{NTU}$ & - & - \\
\hline
\end{tabular}

All values except for $\mathrm{pH}$ and turbidity are expressed in $\mathrm{mg} / \mathrm{L}$.

pH 10 (dose of $50 \mathrm{mg} / \mathrm{L}$ ) [29]. A similar observation was seen from the findings by Zhang et al. [30], where the lowest turbidity removal percentages recorded using cactus Opuntia were at $\mathrm{pH} 6$ and 7 while the optimum $\mathrm{pH}$ was 10 for synthetic kaolin wastewater treatment. This might be due to the properties of the banana stem juice during preparation since it was prepared in a solution form where distilled water was mixed with the juice to make the juice more diluted; hence, the concentration of inulin from the banana stem was lower.

4.5. Effect of Dosage of Banana Stem Juice. Figure 4 shows the effect of the dosage of banana stem juice as a coagulant on flocculation effectiveness at optimum $\mathrm{pH}$ value 7 for banana stem juice. This $\mathrm{pH}$ value was selected based on our findings in this study reported above. For banana stem juice, the dosages ranged from 50 to $100 \mathrm{~mL}$, and the volume of spent coolant wastewater used was $300 \mathrm{~mL}$.

Turbidity removal percentages showed marginal difference in which more than $98 \%$ removal was achieved. It appeared that the highest COD removal percentage was $80.1 \%$ while for the suspended solid removal percentage was $88.6 \%$ (both $90 \mathrm{~mL}$ dosage). The lower COD and SS removal percentages might be due to the use of natural coagulant which may increase the organic load in water [31] and result in the possibility for undesired and increased microbial activity [26]. As such, increase in the organic load is responsible for the increase of BOD concentration and subsequently contributes to increased COD concentration in an aqueous solution.

Table 4 analyses the compliance of COD, SS, and turbidity concentrations of spent coolant wastewater treated with banana stem juice with standard effluent discharge limits $\mathrm{A}$ and $\mathrm{B}$ stipulated by the Department of Environment (DOE), Malaysia. The $\mathrm{pH}$ value of treated spent coolant wastewater complied with the $\mathrm{pH}$ range (5-8) stipulated by the DOE, Malaysia. However, values for all other parameters were higher than standards A and B. Although banana stem juice is capable of reducing the COD, SS, and turbidity concentrations by giving the values of $30,300 \mathrm{mg} / \mathrm{L}(80.1 \%)$, $1,010 \mathrm{mg} / \mathrm{L}$ (88.6\%), and 1,235 NTU (98.5\%), respectively, these values were still higher than standards A and B. The result from this study indicates that banana stem juice is applicable as a natural coagulant in the pretreatment process of wastewater, and further treatment is needed before it can be discharged into the environment. Nevertheless, banana stem juice showed high potential as a natural coagulant for water treatment purposes.

\section{Conclusion}

Generally, the percentage of COD, SS, and turbidity removal by using banana stem juice showed tremendous potential as a plant-based natural coagulant in the treatment of spent 
coolant wastewater. High COD, SS, and turbidity removal percentages by the banana stem juice were observed for effluent at $\mathrm{pH} 7$ where percentages were 80.1, 88.6, and $98.5 \%$, respectively. Banana stem juice contains polysaccharide compounds-inulin $(1.22016 \mathrm{mg} / \mathrm{mL})$, which is a natural polymer for bridging and entrapping the microfloc to form larger floc. Therefore this will help in fast settlement of the floc for coagulation of spent coolant wastewater. Although the final discharge did not comply with the standard effluent discharge limits A and B stipulated by the DOE, Malaysia, with percentage of COD, SS, and turbidity removal exceeding $80 \%$, it is suggested that banana stem juice is to be used in the pretreatment stage of spent coolant wastewater prior to secondary treatment. It is also suggested that banana stem should be dried and sieved into fine powder in order to get high concentration of inulin prior to its use. For future study, it is recommended that more experiment should be done such as colour removal, strength of the flocs, and density of the flocs where those parameters influence the floc velocity.

\section{Acknowledgments}

The authors gratefully acknowledge Research Management Institute (RMI), Universiti Teknologi MARA Malaysia for providing the research grant for this study, Faculty of Chemical Engineering, Universiti Teknologi MARA, Malaysia, and Universiti Teknologi MARA, Sarawak Campus, for technical support.

\section{References}

[1] N. Hilal, G. Busca, F. Talens-Alesson, and B. P. Atkin, "Treatment of waste coolants by coagulation and membrane filtration," Chemical Engineering and Processing, vol. 43, no. 7, pp. 811-821, 2004.

[2] M. Kobya, C. Ciftci, M. Bayramoglu, and M. T. Sensoy, "Study on the treatment of waste metal cutting fluids using electrocoagulation," Separation and Purification Technology, vol. 60, no. 3, pp. 285-291, 2008.

[3] C. Chenga, D. Phippsa, R. M. Alkhaddar, and R. M., "Treatment of spent metalworking fluids," Water Research, vol. 39, no. 17, pp. 4051-4063, 2005.

[4] M. Sokovic and K. Mijanovic, "Ecological aspects of the cutting fluids and its influence on quantifiable parameters of the cutting processes," Journal of Materials Processing Technology, vol. 109, no. 1-2, pp. 181-189, 2001.

[5] M. Greeley and N. Rajagopalan, "Impact of environmental contaminants on machining properties of metalworking fluids," Tribology International, vol. 37, no. 4, pp. 327-332, 2004.

[6] S. Rios, C. Pazos, and J. Coca, "Destabilization of cutting oil emulsions using inorganic salts as coagulants," Colloids and Surfaces A, vol. 138, no. 2-3, pp. 383-389, 1998.

[7] C. Solisio, A. Lodi, A. Converti, and M. Del Borghi, "Removal of exhausted oils by adsorption on mixed Ca and Mg oxides," Water Research, vol. 36, no. 4, pp. 899-904, 2002.

[8] J. M. Benito, S. Ebel, B. Gutierrez, C. Pazos, and J. Coca, "Ultrafiltration of a waste emulsified cutting oil using organic membranes," Water, Air, and Soil Pollution, vol. 128, no. 1-2, pp. 181195, 2004.

[9] N. Hilal, G. Busca, N. Hankins, and A. W. Mohammad, "The use of ultrafiltration and nanofiltration membranes in the treatment of metal-working fluids," Desalination, vol. 167, no. 1-3, pp. 227238, 2004.

[10] M. Belkacem, H. Matamoros, C. Cabassud, Y. Aurelle, and J. Cotteret, "New results in metal working wastewater treatment using membrane technology," Journal of Membrane Science, vol. 106, no. 3, pp. 195-205, 1995.

[11] J. V. G. Christopher and P. I. Thompson, "Effects of $\mathrm{pH}$ amendment on metal working fluid wastewater biological treatment using a defined bacterial consortium," Biotechnology and Bioengineering, vol. 89, no. 3, pp. 357-366, 2005.

[12] H. B. Schrever and R. W. Coughlin, "Effects of stratification in a fluidized bed bioreactor during treatment of metalworking wastewater," Biotechnology and Bioengineering, vol. 63, no. 2, pp. 129-140, 1999.

[13] B. R. Kim, D. N. Rai, J. F. Zemla, F. Lipari, and P. V. Harvath, "Biological removal of organic nitrogen and fatty acids from metal-cutting-fluid wastewater," Water Research, vol. 28, no. 6, pp. 1453-1461, 1994.

[14] C. Cheng, D. Phipps, and R. M. Alkhaddar, "Thermophilic aerobic wastewater treatment of waste metalworking fluids," Water and Environment Journal, vol. 20, no. 4, pp. 227-232, 2006.

[15] K. Takada, Y. Kondo, K. Yamaguchi, and S. Sakamoto, "Study on recycling of waste water from spent water-soluble coolant," Journal of Mechanical Science and Technology, vol. 24, no. 1, pp. 267-270, 2010.

[16] Proceedings on Workshop on "Integrated Approaches in Banana Disease Management" Maeps, Serdang, Malaysia, March 2011.

[17] C. Namasivayam, N. Kanchana, and R. T. Yamuna, "Waste banana pith as adsorbent for the removal of Rhodamine-B from aqueous solutions," Waste Management, vol. 13, no. 1, pp. 89-95, 1993.

[18] C. Namasivayam, D. Prabha, and M. Kumutha, "Removal of direct red and acid brilliant blue by adsorption on to banana pith," Bioresource Technology, vol. 64, no. 1, pp. 77-79, 1998.

[19] K. S. Low, C. K. Lee, and A. C. Leo, "Removal of metals from electroplatinc wastes using banana pith," Bioresource Techno$\log y$, vol. 51, no. 2-3, pp. 227-231, 1995.

[20] APHA, Standard Methods for the Examination of Water and Wastewater, American Public Health Association, New York, NY, USA, 20th edition, 1999.

[21] D. Deepak, K. V. Anand, and R. Bhargava, "Biodegradation of metal cutting oil: evaluation of kinetic parameters," Chemical Engineering Journal, vol. 56, pp. B91-B96, 1994.

[22] DTI, "Development of an integrated membrane bioreactor system for the treatment of used cuttingfluids and other oily wastes in the engineering industry," DTI/BMB/39/1500/ 98/10, 1998.

[23] J. R. Portela, J. Lopez, E. Nebot, and E. Martinez de la Ossa, "Elimination of cutting oil wastes by promoted hydrothermal oxidation," Journal of Hazardous Materials, vol. 88, no. 1, pp. 95106, 2001.

[24] C. J. Van der Gast, A. S. Whiteley, and I. P. Thompson, “Temporal dynamics and degradation activity of an bacterial inoculum for treating waste metal-working fluid," Environmental Microbiology, vol. 6, no. 3, pp. 254-263, 2004.

[25] K. Bilba, M. A. Arsene, and A. Ouensanga, "Study of banana and coconut fibers. Botanical composition, thermal degradation and textural observations," Bioresource Technology, vol. 98, no. 1, pp. 58-68, 2007.

[26] W. J. M. Meijer and E. W. J. M. Mathijssen, "Analysis of crop performance in research on inulin, fibre and oilseed crops," Industrial Crops and Products, vol. 5, no. 4, pp. 253-264, 1996. 
[27] T. F. Tadros, A. Vandamme, B. Levecke, K. Booten, and C. V. Stevens, "Stabilization of emulsions using polymeric surfactants based on inulin," Advances in Colloid and Interface Science, vol. 108-109, pp. 207-226, 2004.

[28] A. C. Eissens, G. K. Bolhuis, W. L. J. Hinrichs, and H. W. Frijlink, "Inulin as filler-binder for tablets prepared by direct compaction," European Journal of Pharmaceutical Sciences, vol. 15, no. 1, pp. 31-38, 2002.

[29] L. G. Torres, S. L. Carpinteyro-Urban, and M. Vaca, "Use of prosopis laevigata seed gum and opuntia ficus-indica mucilage for the treatment of municipal wastewaters by coagulation-flocculation," Natural Resources, vol. 3, pp. 35-41, 2012.

[30] J. Zhang, F. Zhang, Y. Luo, and H. Yang, "A preliminary study on cactus as coagulant in water treatment," Process Biochemistry, vol. 41, no. 3, pp. 730-733, 2006.

[31] K. A. Ghebremichael, K. R. Gunaratna, H. Henriksson, H. Brumer, and G. Dalhammar, "A simple purification and activity assay of the coagulant protein from Moringa oleifera seed," Water Research, vol. 39, no. 11, pp. 2338-2344, 2005.

[32] Department of Environment, Malaysia, Environmental quality (Sewage and Industrial Effluent) Regulation 1979, Third schedule environmental quality act http://www.doe.gov.my/portal/ legislation-actsregulation-order/, 2011.

[33] A. Ndabigengesere, K. Subba Narasiah, and B. G. Talbot, "Active agents and mechanism of coagulation of turbid waters using Moringa oleifera," Water Research, vol. 29, no. 2, pp. 703-710, 1995.

[34] C. Y. Yin, S. Abdul-Talib, Y. P. Lim, M. S. N. Ismail, S. N. A. Abdul-Razak, and A. M. Mohd-Mohtar, "Turbidity removal from surface waters and landfill leachate using cactus opuntia," Journal of the Institute of Engineers, Malaysia, vol. 68, pp. 61664, 2007. 

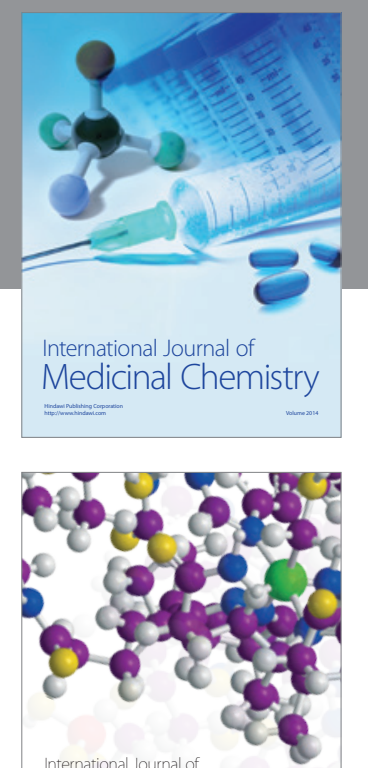

\section{Carbohydrate} Chemistry

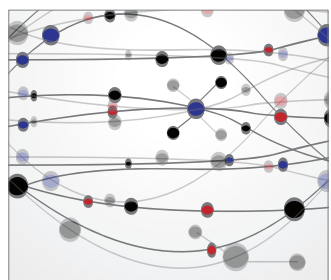

The Scientific World Journal
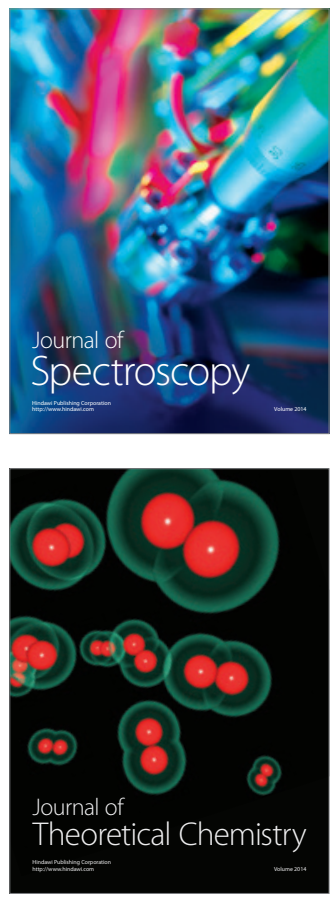
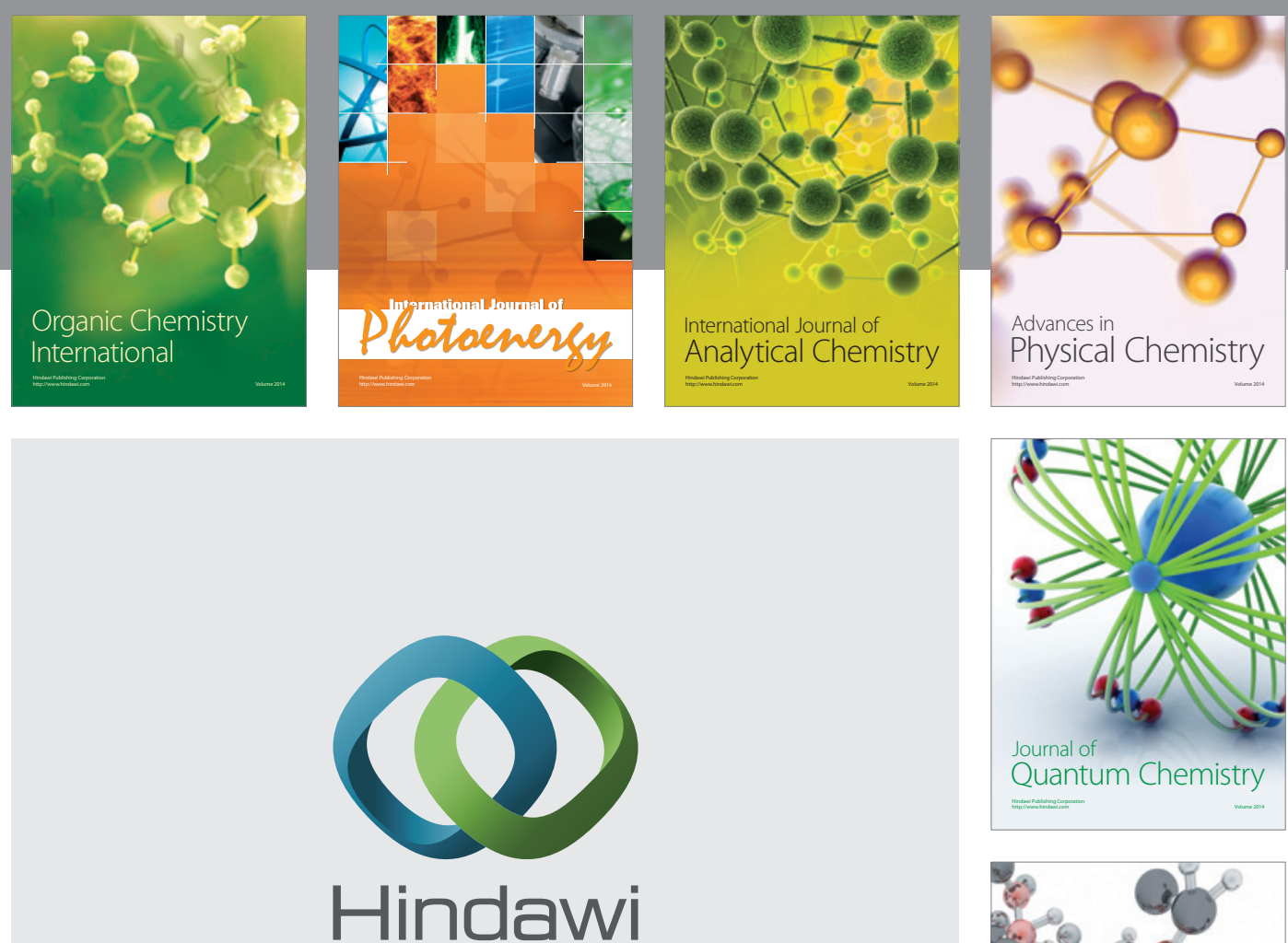

Submit your manuscripts at

http://www.hindawi.com

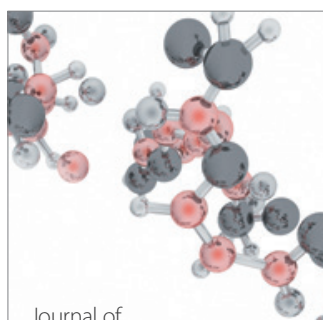

Analytical Methods

in Chemistry

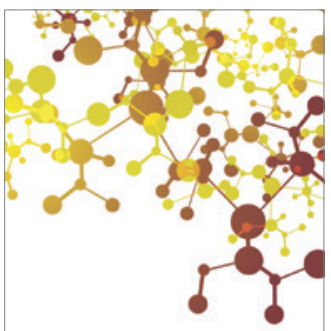

Journal of

Applied Chemistry

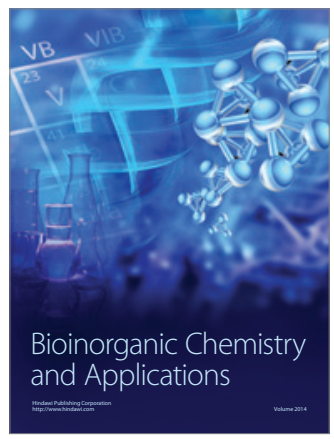

Inorganic Chemistry
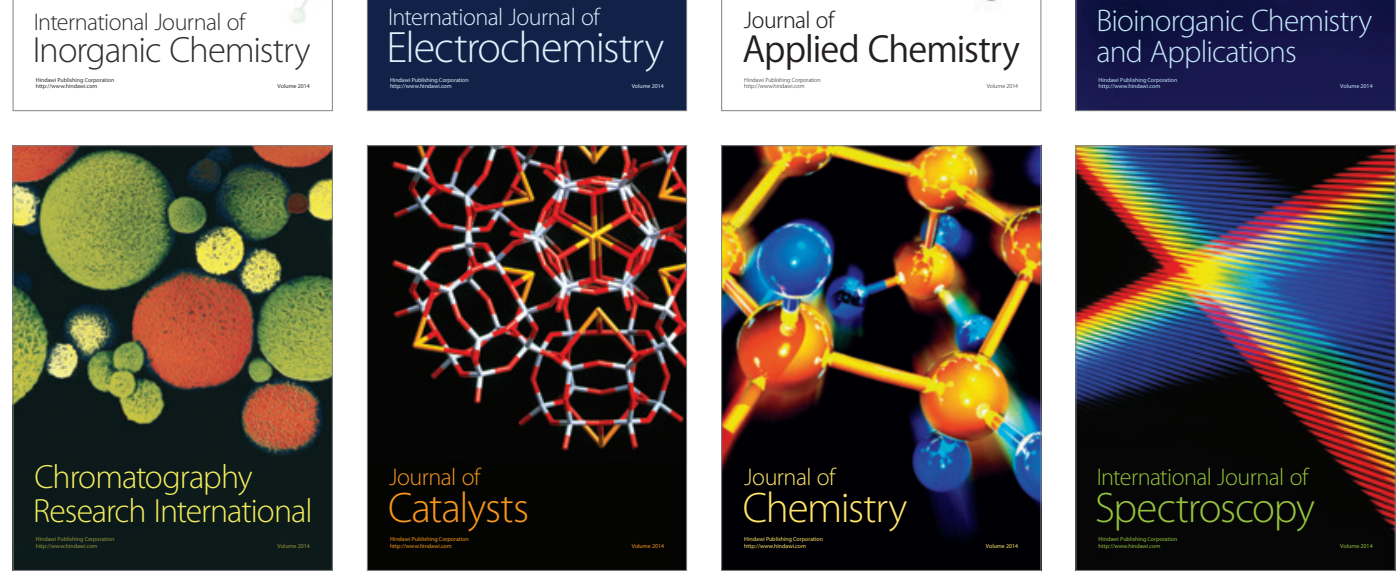